\title{
A Conceptual Review on the Effect of Attitudes towards Retirement on Saving Intentions and Retirement Planning Behavior
}

\author{
Rozilah Shabor Rameli* and Maran Marimuthu \\ Universiti Teknologi Petronas, Department of Management and Humanities, 32610, Bander Seri Iskander, Perak, Malaysia
}

\begin{abstract}
Retirement planning has been the major concern for many years and is becoming an increasingly prominent issue faced by people nowadays. Retirement planning behavior is defined as people's behavior towards their retirement planning. Therefore, attitudes toward retirement might lead to the formation of saving intentions to perform the retirement planning behavior. Past studies have indicated that planning has impacted on the saving behavior as well as to the portfolio choice. It is further emphasized that those planners who have retirement planning arrive close to retirement have a high level of wealth and show higher financial literacy than non-planners. The necessity of individuals to increase retirement savings had over a wide promoted, however, the understanding on individual motivation towards savings at higher rates still remains sparse. For those employees who are willing to retire from work, they should have enough savings to cover their needs during retirement. Unfortunately, findings from previous study showed that many people do not start to prepare and save for their retirement till very late in life-cycle, and do not manage to have adequate savings for their retirement. As a contribution to the literature, the present paper theoretically conceptualizes specifically only on the role of savings intention as a mediator between attitudes toward retirement and retirement planning behavior. Drawing on the theory of planned behavior, it is suggested that the behavioral intention is the closest predictor of behavior. Hence, the stronger the intention to perform a behavior, the greater the probability that the behavior should occur. The recommendations for future studies are proposed.
\end{abstract}

\section{Introduction}

In Malaysia, retirement scheme is divided into two categories, which are: (1) a defined benefit (DB) scheme which is basically known as a government pension system provided for the civil servants; and (2) a defined contribution (DC) scheme which is known as Employees Provident Fund (EPF) provided for employees in the private sector. Currently, those civil servants who chose on the government pension scheme have no strain on post-retirement expenses because of the pensionable employees who are retirees from Government service is eligible for the monthly payment. The rate of pension to be paid depends on the period of reckonable service and the last drawn salary (substantive) by the employees (JPAPencen, 2018). However, for those employees who are working in the private sector, the government policy makes it compulsory for the employers and employees to contribute to the EPF account at the current rate of 11 and 12 percent of monthly salary respectively. The withdrawal in EPF account can be made in a lump-sum amount or partial amount upon the employees reaching age 55 years old. Besides that, employees also may choose monthly payments until they reach the age of 100 (EPF, 2018a, 2018b).

Consequently, those employees who opt for DC scheme are confronted with a wide range of saving decision (Lusardi \& Mitchelli, 2007). Most employees recognize that they are eager to have leisure during retirement and they imagine being able to maintain their current lifestyle after retirement. However, most employees just know a little about a good planning behavior that will facilitate the lifestyle they desire as retirees. The current situation showed that well recognized people are very passive in making decisions toward retirement (Choi, Laibson, Madrian, \& Metrick, 2002). Recently, the way in which how people spend the money, saving their income, making an investment and managing the risk to protect their living standards during retirement also have been impacted due to the changes in the economy. The primary responsibility for providing an adequate income has slowly being transferred from governments and employers to the individual. Therefore, those individuals who are responsible for the complex problem of saving and investing to provide a secure retirement income might not have either the information or the training to manage the task. However, planning has impacted on the saving behavior as well as to the portfolio choice. Thus, planning is associated with higher retirement wealth. Lusardi and Mitchell (2007), further emphasized that those planners who have retirement

* Corresponding author: rozilah_g03683@utp.edu.my 
planning arriving close to retirement have a high level of wealth and show higher financial literacy than non-planners. Furthermore, surprisingly, in Malaysia, most people tend to put retirement planning at the bottom of the list, as they believe that they can rely on the accumulated savings in Employees Provident Fund (EPF) to sustain their retirement years. The issues are whether the amount saved only in the EPF account will be sufficient to cushion the pensioners all through their retirement age. Unfortunately, the EPF savings alone may not be sufficient to fund a comfortable living after retirement (Caraher, 2000). In fact, those Malaysians who depend on a little nest egg built up through EPF funds, which might not be essentially adequate to sustain their retirement years (Tan, 2015). Although EPF can be an important source of retirement income it may not be sufficient to finance the total retirement needs.

For those employees who are willing to retire from work, they should have enough savings to cover their needs during retirement. Past studies found that many people do not start to prepare and save for their retirement till very late in life-cycle, and they do not manage to have an adequate saving for their retirement (Lusardi \& Mitchell, 2008; Mitchell \& Utkus, 2003). Research in behavioral finance suggests a breakdown of willpower and self-control which might explain why many people might deviate from rational behavior in which they can attempt to boost self-interest, yet it is additionally perceived that such decisions are frequently made not as much as a perfect outcome (Mitchell \& Utkus, 2003). Consequently, the requirement of savings among individuals contrasts from one to another due to differences in mindset, behavior, knowledge, and social environment. Past research which used the theory of planned behavior (TPB) has been widely applied and this theory is presented to be a strong variable in behavioral context (Conner \& Armitage, 1998). Thus, this paper used TPB to focus specifically on the impact of attitude on the intention and behavior. Specifically, the objective of this study is to examine the impact of attitudes towards retirement on saving intentions and retirement planning behavior.

\section{Literature Review and Theoretical Background}

\subsection{Attitudes towards Retirement and Retirement Planning Behavior}

Attitude refers to internal psychological tendencies based on positive or negative judgments on a matter, or action towards the subject (Eagly \& Chaiken, 1993). Thus, in this study, the attitude towards retirement and retirement planning behavior is an internal psychological condition influenced by positive or negative judgments related to the behavior. Previous studies indicated that attitudes toward retirement and retirement planning have a significant relationship. Planning has been found to be beneficial for all level of income, either higher or lower income. Thus, planning is the key to wealth creation rather than wealth being the causal factor for planning (Lusardi \& Mitchell, 2007). On the other hand, some of the past studies from Turner, Bailey, and Scott (1994), found that there is a significant but minimal relationship between attitudes toward retirement and retirement planning. This happens when the respondents have more dependent children. Therefore, the older males with higher levels of education, higher occupational status, and more income would have more positive attitudes toward retirement and have planned more for their retirement life.

Attitudes toward retirement are the important factor that influences retirement planning behavior and people tend to have a good planning for their retirement (Hassan et al., 2016; Moorthy et al., 2012). Mutran, Reitzes, and Fernandez (1997), found that those employees who were more active in their retirement planning were more positive in their attitudes toward retirement. The individuals may feel they have some control in shaping a positive retirement experience when they have more planning for retirement. Significantly, people who had positive attitudes toward retirement would be able to achieve adequate retirement savings and tend to relax (Moorthy et al., 2012). Besides that, Malaysian academicians had a positive attitude towards retirement which is about 49.8 percent of the respondents. The study indicated that retirement planning should start more than 20 years before retirement (Moorthy et al., 2012).

\subsection{Saving Intentions}

Previous studies on psychological savings have tended to differentiate between savers and non-savers group without taking into account the element of their intention (Rabinovich \& Webley, 2007). In particular, studies have been made separately about the differences in motives and savings intentions (Canova, Rattazzi, \& Webley, 2005), as well as motives associated with savings (Nyhus \& Webley, 2001), regardless of awareness in intention issues in empirical trials to predict actual savings. Therefore, in future research, it is desirable to control the intensity of the intention and degree of plan realization. (Rabinovich \& Webley, 2007). Nevertheless, the intention is a central factor in the theory of planned behavior and assumed to directly influence behavior due to its indication of how much effort people are willing to exert to perform a specific behavior (Ajzen, 1991; Armitage \& Conner, 2001).

Commonly, savings behavior with regards to the financial decision in which that he or she is highly aware and deliberate about in this matter. For instance, the decision to allocate income for retirement savings (Madrian \& Shea, 2001). According to Canova et al. (2005), in the first case, savings has the aim of assuring for the individual independence and autonomy. However, in the second case, savings has the goal of guaranteeing and maintaining a good 
standard of living after retirement. As a result, saving for retirement is important to guarantee gratification in this period of life. Therefore, people who actively save for retirement tend to have a higher level of retirement preparedness and confidence (Joo \& Pauwels, 2002). It is assumed that someone will take the necessary action as long as he/she has the intention to save. However, savings are estimated to require complicated tasks which requires careful planning and efforts of self-control (Thaler \& Shefrin, 1981).

Notwithstanding, previous research who touched on the financial behavior that are based on the theory of planned behavior (TPB) such as retirement savings (Croy, Gerrans, \& Speelman, 2010), savings habits (Loibl, Kraybill, \& DeMay, 2011), and saving and financial behavior (Shim, Serido, \& Tang, 2012) definitely showed that attitude influences intention. According to Croy et al. (2010), this study revealed that by using the TPB, attitudes have given a high variation in behavioral intentions. Consequently, the result of TPB is confirmed to be a powerful model to predict behavioral intentions and revealed that the variables under TPB have highly influential antecedents of intention in the retirement savings domain (i.e., extra contribution and investment strategy change). Furthermore, the results from Loibl et al. (2011), revealed that attitude and intention have the strongest correlation. Therefore, overall results signified that TPB variables (i.e., intention to save, attitudes toward savings, subjective norm, and perceived behavioral control) have strong significance with savings habits. Besides that, Shim et al. (2012), this study showed that young people's attitude toward savings is the most important predictor in his behavioral intention as demonstrated by the TPB model.

Past literature proposed that people are more inclined to have savings plans when they think ahead. However, studies have been made separately about the differences in motives and savings intentions, as well as motives associated with savings. Thus, the awareness of intention issues in empirical trials to predict actual savings has been ignored. However, there are some processes involving young people who have been studied earlier so far for understanding the process of savings such as the process they choose to save or the relationship between the action to save as well as the performance of future-oriented financial behaviors. Previous studies on psychological savings have tended to differentiate between savers and non-savers group specifically on savings for retirement planning without considering the element of their intention, the present paper fills the indicated research gap.

Therefore, this paper seeks to establish the extent to which attitudes and savings intention drive into the retirement planning behavior.

\subsection{Theory of Planned Behavior and Conceptual Framework}

The Theory of Planned Behavior (TPB) was proposed by Ajzen (1991) as an extension of the Theory of Reasoned Action (TRA). The theory of reasoned action was first presented by Fishbein (1979), and formally defined, developed, and tested in the 1970s. This theory was developed to the better understanding relationship between attitudes, intentions, and behavior. Therefore, the concept of TPB was developed to improve the predictive power of the TRA by including perceived behavioral control to determine the behavioral intention and behavior (Madden, Ellen, \& Ajzen, 1992).

TPB focused on factors that determine people's actual behavioral choices. The purpose of TPB is to predict and understand human behavior in specific context. This theory has explained relevance to the human behavior which was guided by three kinds of behavioral intentions: (1) the positive and negative power of attitudes about the target behavior, (2) subjective norms, and (3) perceived behavioral control (Ajzen, 1991). However, this paper only focusses on the impact of attitudes to the intention and behavior.

In TPB, behavioral intention is the closest predictor of behavior. Thus, intentions refer to the demonstrative of how hard people are willing to make a great effort and the effort they are planning to influence their undertaking on the behavior (Ajzen, 1991). In the review of the relationship between intention and behavior, Sheeran (2002), assumed that intention construct is central to the theories concerning with attitude-behavior relations and therefore to the development of a model in the context of this study. Of the theories and models developed to examine the attitudebehavior relationship, it would appear that asking people how they intend to behave is the channel to knowing how they will actually behave. Consequently, the behavioral intentions refer to the people's decision to perform a particular action.

On the other hand, attitude towards behavior refers to how an individual views the behavior, which can be perceived as desirable or otherwise (Ajzen, 1991). The evidence from numerous studies, (Croy et al., 2010; Fitzmaurice, 2005; Loibl et al., 2011; Louis, Davies, Smith, \& Terry, 2007; Rickwood, 2017; Shim et al., 2012; Smith, Terry, \& Hogg, 2006) which indicated that attitudes are positively related to the behavioral intentions. Consequently, the stronger the intention to perform a behavior, the greater the probability that the behavior should occur. Based on the presented theoretical and empirical arguments, this paper developed the following hypotheses:

H1 Attitudes toward retirement have a significant impact on the retirement planning behavior through the mediating effect on savings intention. 


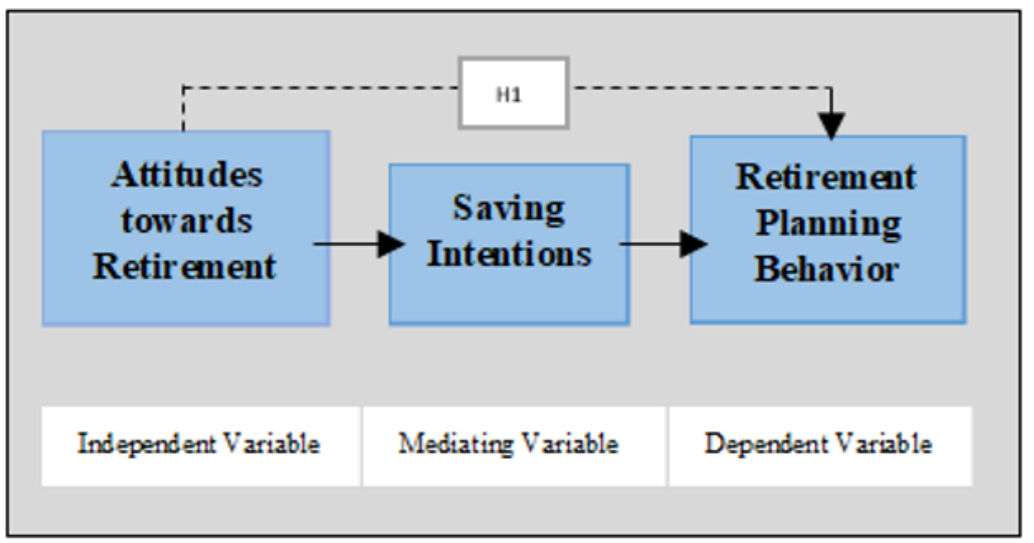

Fig 1: Conceptual framework

Based on the above discussion, Fig. 1 displays a proposed conceptual framework. As one of the key determinants of the retirement planning behavior, it is proposed that attitudes toward retirement affect the retirement planning behavior through the mediating role of saving intentions.

\section{Methodology}

\subsection{Research Design}

This paper is to examine the impact of factors that affect the retirement planning behavior. This study mainly used a primary data will be collected through a survey. The survey employed the quantitative method using the selfadministered questionnaire. The target population is the Malaysian Oil and Gas skilled employees.

\subsection{Sample and Procedure}

The cross-sectional study, using a purposive sampling method because of the limitation in cost and accessibility to the list of the population. The purposive sampling is a nonprobability sampling technique in which an experienced individual selects the sample based on his or her judgment about some appropriate characteristics required of the sample member (Zikmund, Babin, Carr, \& Griffin, 2013). Cooper, Schindler, and Sun (2006), suggested that researchers should not hesitate to use nonprobability sampling procedures because these approaches not only can often appear to give acceptable results, therefore it also can satisfy the objectives of sampling. The data collection will carry out using SPSS for statistical software and PLS-SEM analytical for testing the relationship among hypotheses.

\section{Conclusion}

Planning has impacted the saving behavior as well as to the portfolio of choice. Thus, planning is associated with higher retirement wealth. Previous studies further emphasized that those planners who have retirement planning arrive close to retirement have a high level of wealth and show higher financial literacy than non-planners. Subsequently, literature also proposed that people are more inclined to have savings plans when they think ahead. This paper discussed the body of literature that deals with the possible factors that predicts retirement planning behavior. Therefore, as a contribution to the literature, the present paper theoretically conceptualizes specifically only on the role of savings intention as a mediator between attitudes toward retirement and retirement planning behavior. Drawing on the theory of planned behavior, it is suggested that the behavioral intention is the closest predictor of behavior. Hence, the stronger the intention to perform a particular behavior, the greater the probability that the behavior should actually occur.

For future studies, researchers need to further explore on the knowledge construct and the factors contributing to the retirement planning by specifically including the elements of behavioral finance. Behavioral finance addressed the people's actual behavior which is under complications of mental or emotional constraints when related with decision making process (Mitchell \& Utkus, 2003). Consequently, to understand why people are saving so little and how to get people increase their saving for retirement, the behavioral finance which addressed the issues raised by bounded rationality and bounded self-control could be incurred into behavioral theory. As a result, to address the growing need for individuals who are close to retirement years, a better understanding of the factors contributing to successful transition negotiations for retirement life must be obtained. 


\section{References}

Ajzen, I. (1991). The theory of planned behavior. Organizational behavior and human decision processes, 50(2), 179211.

Armitage, C. J., \& Conner, M. (2001). Efficacy of the theory of planned behaviour: A meta-analytic review. British Journal of Social Psychology, 40(4), 471-499.

Canova, L., Rattazzi, A. M. M., \& Webley, P. (2005). The hierarchical structure of saving motives. Journal of Economic Psychology, 26(1), 21-34.

Caraher, K. (2000). Issues in incomes provision for the elderly in Malaysia. Paper presented at the The year 2000 international research conference on social security, Helsinki.

Choi, J. J., Laibson, D., Madrian, B. C., \& Metrick, A. (2002). Defined contribution pensions: Plan rules, participant choices, and the path of least resistance. Tax policy and the economy, 16, 67-113.

Conner, M., \& Armitage, C. J. (1998). Extending the theory of planned behavior: A review and avenues for further research. Journal of applied social psychology, 28(15), 1429-1464.

Cooper, D. R., Schindler, P. S., \& Sun, J. (2006). Business research methods (Vol. 9): McGraw-Hill Irwin New York.

Croy, G., Gerrans, P., \& Speelman, C. (2010). The role and relevance of domain knowledge, perceptions of planning importance, and risk tolerance in predicting savings intentions. Journal of Economic Psychology, 31(6), 860871.

Eagly, A. H., \& Chaiken, S. (1993). The psychology of attitudes: Harcourt Brace Jovanovich College Publishers.

EPF. (2018a). $\quad$ Age 55 Years Withdrawal. http://www.kwsp.gov.my/portal/documents/10180/6112185/Risalah_55 Jan2018 05042018.pdf Accessed April 10, 2018

EPF. (2018b). Overview Of The EPF. Retrieved from http://www.kwsp.gov.my/portal/en/about-epf/overview-of-theepf Accessed March 10, 2018

Fishbein, M. (1979). A theory of reasoned action: some applications and implications.

Fitzmaurice, J. (2005). Incorporating consumers' motivations into the theory of reasoned action. Psychology \& Marketing, 22(11), 911-929.

Hassan, K. H., Rahim, R. A., Ahmad, F., Zainuddin, T. N. A. T., Merican, R. R., \& Bahari, S. K. (2016). Retirement Planning Behaviour of Working Individuals and Legal Proposition for New Pension System in Malaysia. $J$. Pol. \& L., 9, 43.

Joo, S.-H., \& Pauwels, V. W. (2002). Factors affecting workers' retirement confidence: A gender perspective.

JPAPencen. (2018). Pension Scheme: Pension Benefit. Retrieved from http://www.jpapencen.gov.my/english/pension benefits.html Accessed April 11, 2018

Loibl, C., Kraybill, D. S., \& DeMay, S. W. (2011). Accounting for the role of habit in regular saving. Journal of Economic Psychology, 32(4), 581-592.

Louis, W., Davies, S., Smith, J., \& Terry, D. (2007). Pizza and pop and the student identity: The role of referent group norms in healthy and unhealthy eating. The Journal of social psychology, 147(1), 57-74.

Lusardi, A., \& Mitchell, O. S. (2007). Baby boomer retirement security: The roles of planning, financial literacy, and housing wealth. Journal of monetary Economics, 54(1), 205-224.

Lusardi, A., \& Mitchell, O. S. (2008). Planning and financial literacy: How do women fare? American Economic Review, 98(2), 413-417.

Lusardi, A., \& Mitchelli, O. S. (2007). Financial literacy and retirement preparedness: Evidence and implications for financial education. Business economics, 42(1), 35-44.

Madden, T. J., Ellen, P. S., \& Ajzen, I. (1992). A comparison of the theory of planned behavior and the theory of reasoned action. Personality and social psychology Bulletin, 18(1), 3-9.

Madrian, B. C., \& Shea, D. F. (2001). The power of suggestion: Inertia in 401 (k) participation and savings behavior. The Quarterly Journal of Economics, 116(4), 1149-1187.

Mitchell, O. S., \& Utkus, S. P. (2003). Lessons from behavioral finance for retirement plan design.

Moorthy, M. K., Durai, T., Chelliah, L., Sien, C. S., Leong, L. C., Kai, N. Z., . . . Teng, W. Y. (2012). A Study on the retirement planning behaviour of working individuals in Malaysia. International Journal of Academic Research in Economics and Management Sciences, 1(2), 54.

Mutran, E. J., Reitzes, D. C., \& Fernandez, M. E. (1997). Factors that influence attitudes toward retirement. Research on aging, 19(3), 251-273.

Nyhus, E. K., \& Webley, P. (2001). The role of personality in household saving and borrowing behaviour. European journal of personality, 15(S1).

Rabinovich, A., \& Webley, P. (2007). Filling the gap between planning and doing: Psychological factors involved in the successful implementation of saving intention. Journal of Economic Psychology, 28(4), 444-461. doi: http://dx.doi.org/10.1016/j.joep.2006.09.002

Rickwood, C. (2017). CUSTOMER INTENTION TO SAVE FOR RETIREMENT USING A PROFESSIONAL FINANCIAL SERVICES PLANNER (Vol. 3).

Sheeran, P. (2002). Intention-behavior relations: a conceptual and empirical review. European review of social psychology, 12(1), 1-36. 
Shim, S., Serido, J., \& Tang, C. (2012). The ant and the grasshopper revisited: The present psychological benefits of saving and future oriented financial behaviors. Journal of Economic Psychology, 33(1), 155-165.

Smith, J. R., Terry, D. J., \& Hogg, M. A. (2006). Who will see me? The impact of type of audience on willingness to display group-mediated attitude-intention consistency. Journal of applied social psychology, 36(5), 11731197.

Tan, H. K. (2015). Financial planning for post-retirement among Urban Malaysians in Klang Valley/Tan Hoe Kock. University of Malaya.

Thaler, R. H., \& Shefrin, H. M. (1981). An economic theory of self-control. Journal of political Economy, 89(2), 392406.

Turner, M. J., Bailey, W. C., \& Scott, J. P. (1994). Factors influencing attitude toward retirement and retirement planning among midlife university employees. Journal of Applied Gerontology, 13(2), 143-156.

Zikmund, W. G., Babin, B. J., Carr, J. C., \& Griffin, M. (2013). Business research methods: Cengage Learning. 